Rodegheri, P.M. and Serra, S.M.B. (2019). "Lean construction and maturity models: five methods applied in the same project." In: Proc. $27^{\text {th }}$ Annual Conference of the International. Group for Lean Construction (IGLC), Pasquire C. and Hamzeh F.R. (ed.), Dublin, Ireland, pp. 1081-1092. DOI: https://doi.org/10.24928/2019/0195. Available at: 〈www.iglc.net>.

\title{
LEAN CONSTRUCTION AND MATURITY MODELS: APPLYING FIVE METHODS
}

\author{
Priscila Mirapalhete Rodegheri ${ }^{1}$, Sheyla Mara Baptista Serra ${ }^{2}$
}

\begin{abstract}
The purpose of this paper is comparing five Maturity Models (MM) developed to measure the company's adherence to Lean Construction (LC) principles. Methods were applied to the same project and results show that project classification was equivalent in the five systems for LC principles adherence. This MM have differences between origins, scope, application and results presentation, showing the diversity existent in LC philosophy. For this case study, all five methods showed adherence to lean principles and the results are graphically presented to easily compare the obtained results from the application of them.
\end{abstract}

\section{KEYWORDS}

Lean Construction, Maturity Models, Continuous Improvement, Action Learning/Research.

\section{INTRODUCTION}

Throughout history, civil construction has been following the technological development of different generations, adapting advances to basic construction concepts. Among these advances, Lean Construction (LC) can be mention as one important development that was conceived by Koskela (1992) applying the principles of Lean Thinking (LT), established in the automobile industry, to construction industry.

From the Koskela (1992) the study, lean practices had been disseminated among companies and construction professionals, bringing benefits to them and others involved. It is estimated that $90 \%$ of professionals how to work with LC in Chile, consider crucial apply this philosophy to get the company growth (Salvatierra et al. 2015). The measurement of improvements results from the application of lean construction is necessary just like any other management systems, after all, "what gets measured gets managed".

The civil construction has different Performance Measurers Systems (PMS), based on results such as Kay Performance Indicators (KPI) and Balanced Scorecard (BSC). PMS is support tools to ensure goals through manage performance, human resources and company strategy ( $\mathrm{Yu}$ et al. 2007). PMS is a set of indicators that measure the efficiency and

1 Master student, Programa de Pós-graduação em Engenharia Civil. Universidade Federal de São Carlos, Brazil, +55 21 98296-3259, eng.priscilamr@ gmail.com

2 Professor, Dr., Departamento de Engenharia Civil. Universidade Federal de São Carlos, Brazil, +55 16 3351-9670, sheylabs@ufscar.br 
effectiveness of organization actions to assess whether goals are met, for Wettstein and Kueng (2002), is a system that follows company performance, supporting results communicating, tactical and strategic decisions and organizational learning. However, Measurement Model (MM) enable implement change in a systematic and directed approach (Nesensohn 2014). After the revelation of the eleven principles proposed by Koskela (1992) and the five guidelines of lean the thinking presented by Womack and Jones (1997), were necessary to invest in MM development focused on LC.

Models based on lean principles can be divided between those that focus on the evaluation of some premises but non-full LC application and those that have extended evaluation of this philosophy. In the first group are the systems based on the Last Planner System (PLS) (Ballard 2000); the parameters suggested by Alarcón et al. (2001), focusing on waste quantification, cycle time and rework; and the evaluation process proposed by Moon et al. (2007) based on Transformation-Flow-Value (TFV).

Among the MM range that gives global LC evaluation, five had been selected in this paper for case study application. Among several models that analyze maturity level focused on LC concepts application, five of them use case study through field visit and interview approach. In addition, selected models were studied in congresses of LC, which led the authors to seek a comparison between them to be used in a construction company study. Two of these are Brazilians, one English, one Chilean and one binational (Brazil and Germany). They have in common the application method through questions and answers tool that allow compeer current state and the goals to be reached along the evolution philosophy journey.

The selected methods for this paper have a semi-qualitative approach. They evaluate the LC principles adhesion in a flexible manner (qualitative) and pointed out the current maturity level (quantitative). As a disadvantage, they are subjective because evaluate a wide range of factors (Sarhan and Fox 2013).

Thus, this work aims to draw a comparison between the evaluation methods proposed by Hofacker et al. (2008), Arantes (2010), Nesensohn (2014), Soto (2016) and Carvalho and Scheer (2017) through a case study of Brazil countryside construction site, located in the state of São Paulo, and presented the advantages and disadvantages of each method and the suited method to this case study.

\section{MATERIALS AND METHODS}

At the first moment, a bibliographic review was carried out in scientific databases searching for "evaluation lean construction", "performance measurement systems lean construction", "maturity model lean construction" were several documents were found. The selected sources are from 2000 to 2018 by different parts of the world, cover case studies, bibliography reviews, proposition and comparison between MM focused on LC.

The verified methodologies used to evaluate maturity in LC, those presented by Hofacker et al. (2008), Arantes (2010), Nesensohn (2014), Soto (2016) and Carvalho and Scheer (2017) were selected for this paper. The choice was given by these models being more embracing about LC and LT among the authors correlated to IGLC. Even with differences in evaluation methodology, way of use and graphic results scale, as will be 
presented below, the foundations and proposal are similar, allowing compare results obtained in the same construction site.

The project of this case study is a residential enterprise composed of fifty houses. The construction company has a small size and was founded in 2015 from a project company joined with a residential construction company, both together ads twelve years of experience in the city of Sorocaba-SP-BR. The project was conceived by shareholders who were the main customer of this enterprise and had been the financing of a public Brazilian house program. When the evaluations was made, the construction was in the finishing phase, with the construction site being reduced, as well as stock, workers and material flow.

The company and the project do not use LC principles in a formal way, even though some interviewees and external suppliers know this philosophy. In the construction site visit, the interviewer observed LC use in an unreasonable way and with limitations to the adoption of some LC principles due to the project nature and requirements of the fomented federal program.

Table 1 present methods specifications used in this work. The research occurred during the professional performance of one of the authors with the project. Below will be presented application details of each system, the application of methods was done as well as proposed by each author.

\section{Lean Construction-Quality Rating Model (LCR)}

The authors of this method suggest that the application should be done by two external researchers who have knowledge of LC and about the questionnaire proposed. On this case study, this MM was applied by one of the authors and another professional who works in the project and know LC. As indicated by Hofacker et al. (2008), the construction site was visited and the principles use could be verified on that. After that, each evaluator completed the same questionnaire evaluating the project and answers were discussed and results analyzed. In the next chapter, the results will be presented in a radar chart according to the proposition of the method author. One site was visited, so the results represent LC maturity in this project.

\section{Lean Construction Diagnostic Model (MDCE)}

Arantes (2010) does not present a name for the developed tool, in this paper will be used MDCE (Modelo de Diagnóstico da Construção Enxuta, in Portuguese), the title of the work that presents it. The authors of the present paper completed the proposed questionnaire after a site visit and dialogues with professional's workers of this project, evaluating just this project. 
Table 1: Comparison between models applied in the same project (own elaboration).

\begin{tabular}{|c|c|c|c|c|c|}
\hline $\begin{array}{l}\text { MODEL } \\
\text { AUTHOR } \\
\text { YEAR }\end{array}$ & BASED ON & EVALUATION FACTORS & EVALUATION METHOD & $\begin{array}{l}\text { RESULTS } \\
\text { SCALE }\end{array}$ & $\begin{array}{c}\text { RESULTS } \\
\text { PRESENTATION }\end{array}$ \\
\hline $\begin{array}{c}\text { LCR } \\
\text { Hofaker et al. } \\
(2008)\end{array}$ & $\begin{array}{l}\text { Principles of LC } \\
\text { developed by } \\
\text { Koskela (1992) } \\
\text { \& principles of } \\
\text { LT developed } \\
\text { by Womack \& } \\
\text { Jones (1996) }\end{array}$ & $\begin{array}{l}1 \text { Client focus } \\
2 \text { Waste consciousness } \\
3 \text { Quality } \\
4 \text { Material flow } \\
5 \text { Organization, planning and info-flow } \\
6 \text { Continuous improvement }\end{array}$ & $\begin{array}{l}\text { Questionnaire with } 30 \\
\text { questions, completed by } \\
\text { external evaluator after a } \\
\text { hour in a construction site } \\
\text { visit evaluating each } \\
\text { question in quantitative } \\
\text { way through a Likert scale } \\
\text { from } 0 \text { to } 4 \text {. Evaluate } \\
\text { construction site, authors } \\
\text { affirm that evaluating } \\
\text { more than } 3 \text { projects } \\
\text { results could be used to } \\
\text { represent whole company. }\end{array}$ & $\begin{array}{l}\text { Percentage scale } \\
\text { of } 4 \text { classes with } 3 \\
\text { subclasses each } \\
\text { (from "d" to "aaa"). } \\
\text { The step of the } \\
\text { grade gradually } \\
\text { lower while the } \\
\text { grade get higher }\end{array}$ & $\begin{array}{l}\text { Radar chart filled } \\
\text { out, presenting } \\
\text { the evaluation for } \\
\text { the } 6 \text { factors }\end{array}$ \\
\hline $\begin{array}{l}\text { MDCE } \\
\text { Arantes, F } \\
(2010)\end{array}$ & $\begin{array}{l}\text { Principles of LC } \\
\text { developed by } \\
\text { Koskela (1992) } \\
\& \text { principles of } \\
\text { LT developed } \\
\text { by Womack \& } \\
\text { Jones (1996) \& } \\
\text { concepts } \\
\text { proposed by } \\
\text { Rentes (2009) }\end{array}$ & $\begin{array}{l}1 \text { Reduce the share of non-value-adding activities } \\
2 \text { Increase output value through systematic } \\
\text { consideration of customer requirements } \\
3 \text { Reduce variability } \\
4 \text { Reduce the cycle time } \\
5 \text { Simplify by minimizing the number of steps and } \\
\text { parts } \\
6 \text { Increase output flexibility } \\
7 \text { Increase process transparency } \\
8 \text { Focus control on the complete process } \\
9 \text { Build continuous improvement into the process } \\
10 \text { Balance flow improvement with conversion } \\
\text { improvement } \\
11 \text { Benchmark }\end{array}$ & $\begin{array}{l}\text { Questionnaire with } 24 \\
\text { questions, completed by } \\
\text { external evaluator through } \\
\text { interviews answers from } \\
\text { agent responsible for } \\
\text { implementing LC } \\
\text { philosophy in the } \\
\text { company. Evaluate project } \\
\text { by site visit and informal } \\
\text { conversation with workers, } \\
\text { authors don't extend the } \\
\text { evaluation to whole } \\
\text { company. }\end{array}$ & $\begin{array}{l}\text { It considers } \\
\text { whether the } \\
\text { principle is } \\
\text { "applied," is in } \\
\text { "development" or } \\
\text { "non applied" and } \\
\text { also if the } \\
\text { company has an } \\
\text { interest in } \\
\text { "implementation" } \\
\text { and sees this as } \\
\text { "opportunity" }\end{array}$ & $\begin{array}{l}\text { Visual framework } \\
\text { proposed by } \\
\text { Rentes (2009), } \\
\text { presenting the } \\
\text { evaluation for the } \\
24 \text { questions }\end{array}$ \\
\hline $\begin{array}{l}\text { LCMM } \\
\text { Nesensohn, C } \\
(2014)\end{array}$ & $\begin{array}{l}\text { Principles of LC } \\
\text { developed by } \\
\text { Koskela (1992) }\end{array}$ & $\begin{array}{l}1 \text { Leadership } \\
\text { - Lean leadership } \\
2 \text { Philosophy } \\
\text { - Customer focus } \\
\text { - Way of thinking } \\
\text { 3 People } \\
\text { - Culture \& behavior } \\
\text { - Competencies } \\
\text { - Improvement Enablers } \\
4 \text { Processes \& system } \\
\text { - Processes \& tools } \\
\text { - Change } \\
5 \text { Outcomes \& outputs } \\
\text { - Work environment } \\
\text { - Business results } \\
6 \text { Learning } \\
\text { - Learning \& competency development }\end{array}$ & $\begin{array}{l}\text { Framework with } 75 \\
\text { statements organized in } \\
11 \text { attributes classified in } 6 \\
\text { layers, completed by } \\
\text { external evaluator after a } \\
\text { construction site visit and } \\
\text { conversations with } \\
\text { employees, evaluating } \\
\text { each attribute in a } \\
\text { quantitative way through a } \\
\text { Likert scale from } 0 \text { to } 4 \text {. } \\
\text { The layers have weights } \\
\text { which are multiplied by the } \\
\text { lowest value of the } \\
\text { attributes belonging to } \\
\text { each layer. Allow project } \\
\text { or company evaluation. }\end{array}$ & $\begin{array}{l}\text { Range of absolute } \\
\text { values of } 5 \\
\text { categories (from } 0 \\
\text { to 4): Uncertain; } \\
\text { Awakening; } \\
\text { Systematic; } \\
\text { Integrated; } \\
\text { Challenging }\end{array}$ & $\begin{array}{l}\text { Radar chart with } \\
\text { markers, } \\
\text { presenting the } \\
\text { evaluation for the } \\
6 \text { attributes }\end{array}$ \\
\hline $\begin{array}{l}\text { MMDPLC } \\
\text { Soto, U } \\
(2016)\end{array}$ & $\begin{array}{l}\text { Principles of LC } \\
\text { developed by } \\
\text { Koskela (1992) } \\
\& \text { principles of } \\
\text { LT developed } \\
\text { by Womack \& } \\
\text { Jones (1996) \& } \\
\text { concepts } \\
\text { proposed by } \\
\text { Diekmann et al. } \\
\text { (2004) }\end{array}$ & $\begin{array}{l}1 \text { Waste disposal } \\
\text { - Optimization of the production system } \\
\text { - Optimization of the work package } \\
\text { - Supply chain management } \\
\text { - Optimization of production planning } \\
2 \text { Standardization } \\
\text { - Visual management } \\
\text { - Definition of work process } \\
\text { - Organization of the workplace } \\
3 \text { Culture / people } \\
\text { - Organization commitment } \\
\text { - People's commitment } \\
\text { - Training } \\
4 \text { Customer focus } \\
\text { - Optimization of value } \\
\text { - Flexibility of resources } \\
5 \text { Continuous improvement / Quality } \\
\text { - Measurement } \\
\text { - Organizational learning } \\
\text { - Defect response } \\
\text { - Error prevention }\end{array}$ & $\begin{array}{l}\text { Self-assessment } \\
\text { questionnaire applied by } \\
\text { internal evaluator, } \\
\text { evaluating } 16 \text { LC practices } \\
\text { on a Likert scale from } 0 \text { to } \\
5 \text {, organized in } 6 \text { principle. } \\
\text { Allow project or company } \\
\text { evaluation. }\end{array}$ & $\begin{array}{l}\text { Range of absolute } \\
\text { values of } 6 \\
\text { categories (from } 0 \\
\text { to 5): Sustainable; } \\
\text { Integrated; } \\
\text { Established; } \\
\text { Formal; Initial; } \\
\text { Non existent }\end{array}$ & $\begin{array}{l}\text { No presentation of } \\
\text { the results model } \\
\text { is proposed }\end{array}$ \\
\hline $\begin{array}{l}\text { DOLC } \\
\text { Carvalho, B. } \\
\text { and } \\
\text { SCHEER, S. } \\
(2017)\end{array}$ & $\begin{array}{l}\text { Principles of LC } \\
\text { developed by } \\
\text { Koskela (1992) } \\
\text { \& Carvalho } \\
\text { (2008) }\end{array}$ & $\begin{array}{l}1 \text { Reduce the share of non-value-adding activities } \\
2 \text { Increase output value through systematic } \\
\text { consideration of customer requirements } \\
3 \text { Reduce variability } \\
4 \text { Reduce the cycle time } \\
5 \text { Simplify by minimizing the number of steps and } \\
\text { parts } \\
6 \text { Increase output flexibility } \\
7 \text { Increase process transparency } \\
8 \text { Focus control on the complete process } \\
9 \text { Build continuous improvement into the process } \\
10 \text { Balance flow improvement with conversion } \\
\text { improvement } \\
11 \text { Benchmark }\end{array}$ & $\begin{array}{l}6 \text { questionnaire, with } \\
\text { about } 30 \text { questions each, } \\
\text { applied by external } \\
\text { evaluators to internal } \\
\text { agents (designer, } \\
\text { engineer, worker, director, } \\
\text { supplier) and external } \\
\text { (client) of the company. } \\
\text { Free answers (qualitative) } \\
\text { that the evaluator should } \\
\text { quantify on a Likert scale } \\
\text { from } 0 \text { to } 3 \text {. Evaluate } \\
\text { construction site, authors } \\
\text { affirm that evaluating } \\
\text { more than } 3 \text { projects, } \\
\text { results could be used to } \\
\text { represent whole company. }\end{array}$ & $\begin{array}{l}\text { Percentage scale } \\
\text { of } 4 \text { classes with } 3 \\
\text { subclasses each } \\
\text { (from "D" to } \\
\text { "AAA"). The steps } \\
\text { are uniform except } \\
\text { the lowest grade } \\
\text { that is bigger than } \\
\text { the others }\end{array}$ & $\begin{array}{l}\text { Radar chart filled } \\
\text { out, presenting } \\
\text { the evaluation for } \\
\text { the } 11 \text { principles } \\
\text { of LC }\end{array}$ \\
\hline
\end{tabular}




\section{Lean Construction Maturity Model (LCMM)}

The MM developed by Nesensohn (2014) evaluate statements related to LC distributed in attributes. The statements should be evaluated after a site visit and dialogues with agents of the project by an external or internal evaluator, being possible a self-assessment. The author affirms the need of calibrating the weight proposed for every attribute by applying the tool in different projects and allow the evaluator to modify them according to the values and vision of the evaluated company (Nesensohn 2017; Nesensohn et al. 2014, 2015).

In this case study were used the author of the method proposed weights and consider just project evaluation instead of company evaluation.

\section{MATURity MOdEL FOR DEVELOPMENT OF LEAN CONSTRUCTION PRINCIPLES (MMDPLC)}

Soto (2016) model, called MMDPLC (Modelo de Madurez para el Desarrollo de los Principios Lean Construction, in Spanish), propose a self-assessment tool that verifies the company's expectation about its adherence to the LC principles and the effective adherence to LC practices. No scale is proposed either a result presentation.

The author applied the proposed model through a site visit and dialogues with professional workers of this project, assessing their expectations and the real application of lean practices just in the project instead of a whole company.

\section{DEGREE OF LEAN CONSTRUCTION (DOLC)}

Of the six questionnaires proposed by Carvalho and Scheer (2017), based on Carvalho (2008), five were applied to the following agents: designer, engineer, worker, director and client. Fill out the supplier questionnaire could not be donned because there was no supplier adherence to the research. Nevertheless, the authors believe that the data collected are representative enough to this paper propose.

Carvalho and Scheer (2017) also recommend the application of this MM through external interviewer that has knowledge of LC in order to answer doubts of the interviewees. Although interviews were carried out with actors from different departments and about company procedures, this model had been applied in one construction site, so the results are just for this project not for all firm.

\section{RESULTS}

Following are the visual tools and radar charts developed by the application of the selected methods according to the previously described methodology. Is possible identify in the charts the evaluated factors, the valuation scale proposed by each author, the project adherence of each factor (through the filleted area in the charts) and the final classification of the project (percentage shown in the legend of the chart). Figure 1 present Hofacker et al. (2008) results in a radar chart with six evaluation factors, project most adherent factor was "client focus" with $54 \%$ and the project range for this method is $45 \%$. 


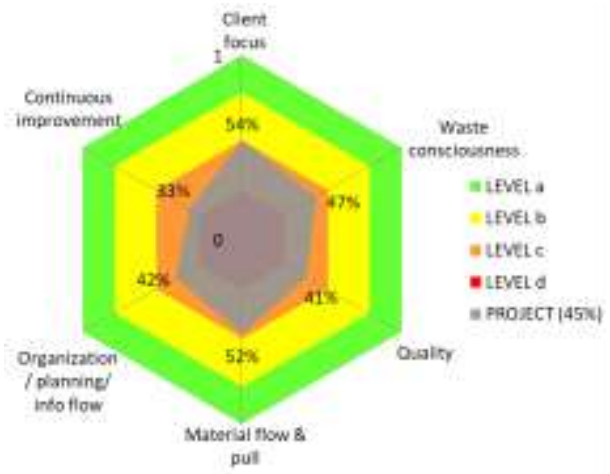

Figure 1: Project evaluation with LCR method (own elaboration).

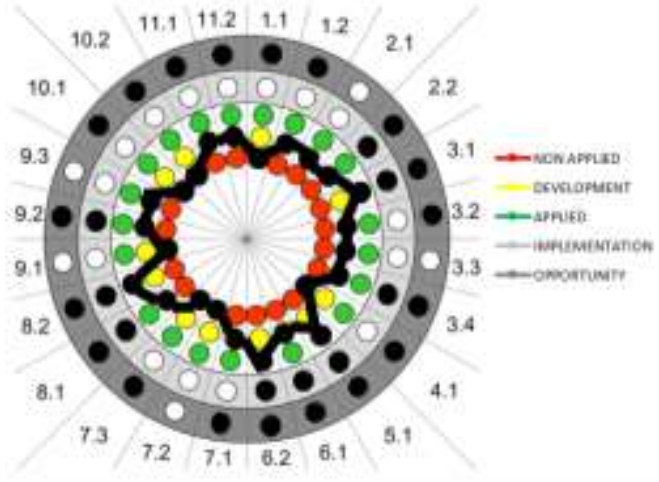

Figure 2: Project evaluation with MDCE original method (own elaboration).

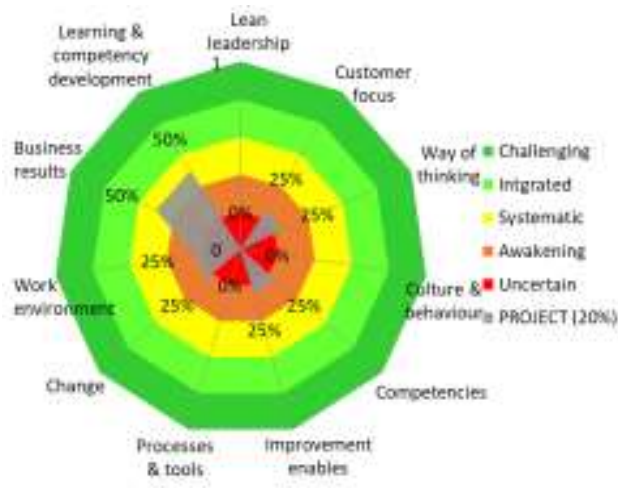

Figure 4: Project evaluation with LCMM original method (own elaboration).

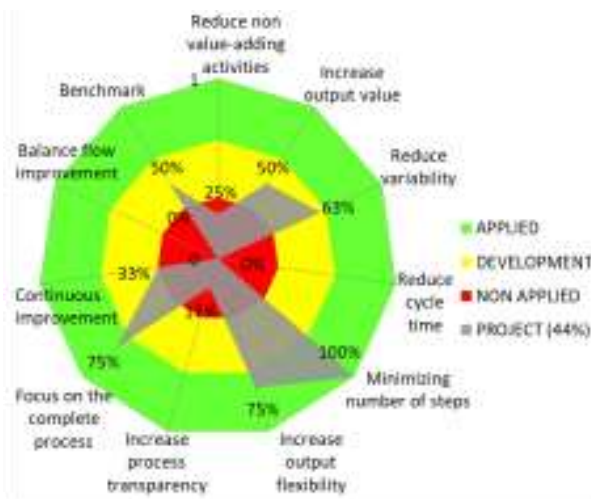

Figure 3: Project evaluation with MDCE adapted method (own elaboration).

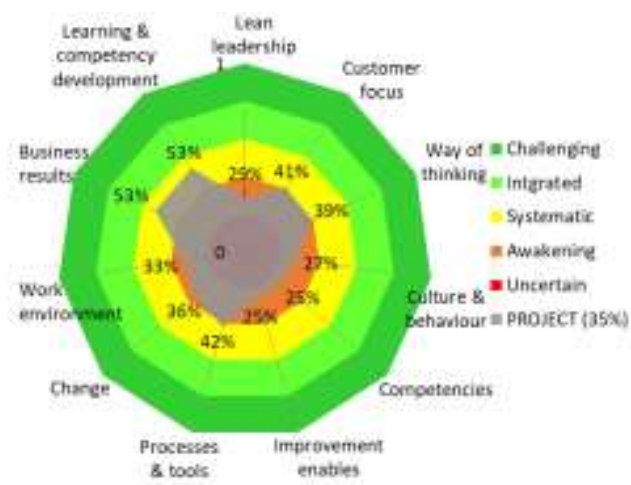

Figure 5: Project evaluation with LCMM adapted method (own elaboration). 


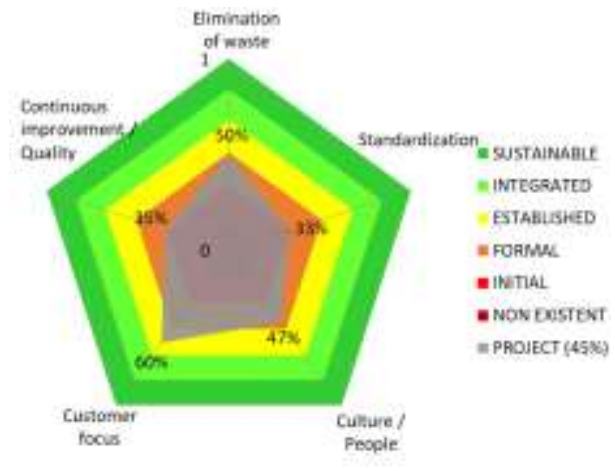

Figure 6: Project evaluation with MMDPLC method (own elaboration).

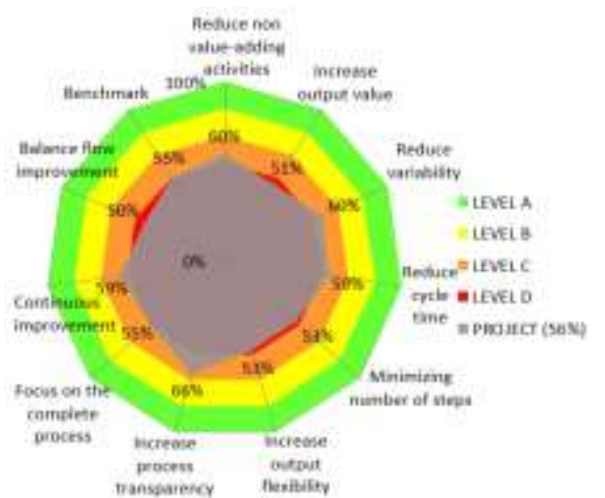

Figure 7: Project evaluation with DOLC method (own elaboration).

Figure 2 present a visual framework proposed by Arantes (2010) with 24 evaluation factors in tree scale results and with two others classifications: if the company has an interest in "implementation" and sees this as an "opportunity". Figure 3 present adapted Arantes (2010) radar char, with attributes evaluation by eleven LC principles by Koskela (1992), the value presented for each principle was the average value of statements related to them, were project had $44 \%$ adhesion.

Figure 4 present radar chart based on original Nesensohn (2014) method, considering the lowest statement value for each attribute, author propose that the project only grow to another level after filleted out all gaps of the current level, were project adhesion to evaluated principles is $20 \%$. Figure 5 present adapted Nesensohn (2014) radar char, with attributes evaluation by statements average value, were project had $35 \%$ adhesion, shown that original the evaluation method is rough in fact. The results scale had been adapted from absolute values to a percentage scale

Figure 6 present Soto (2016) radar chart was project had $45 \%$ adhesion to LC evaluated practices. This method does not present a graphic representation, so the authors adapted the results for this radar chart with percentage scale to better compare with the other methods. Figure 7 present Carvalho (2008) model original radar chart result with 56\% adhesion to $\mathrm{LC}$ principles.

\section{DISCUSSION}

It is observed that the five applied methods have differences and similarities, one of the main difference is the final scale results that classify project adherence to the analyzed parameters. Figure 8 presents a scale comparison of each method classification, showing the project position in each MM.

From the presented scales, those of Hofacker et al. (2008) and Carvalho and Scheer (2017) are originals from the model, the others were adapted, as previously described. Whit exception of Carvalho and Scheer (2017), the ranking levels has homogeneous ascension in lean journey. 

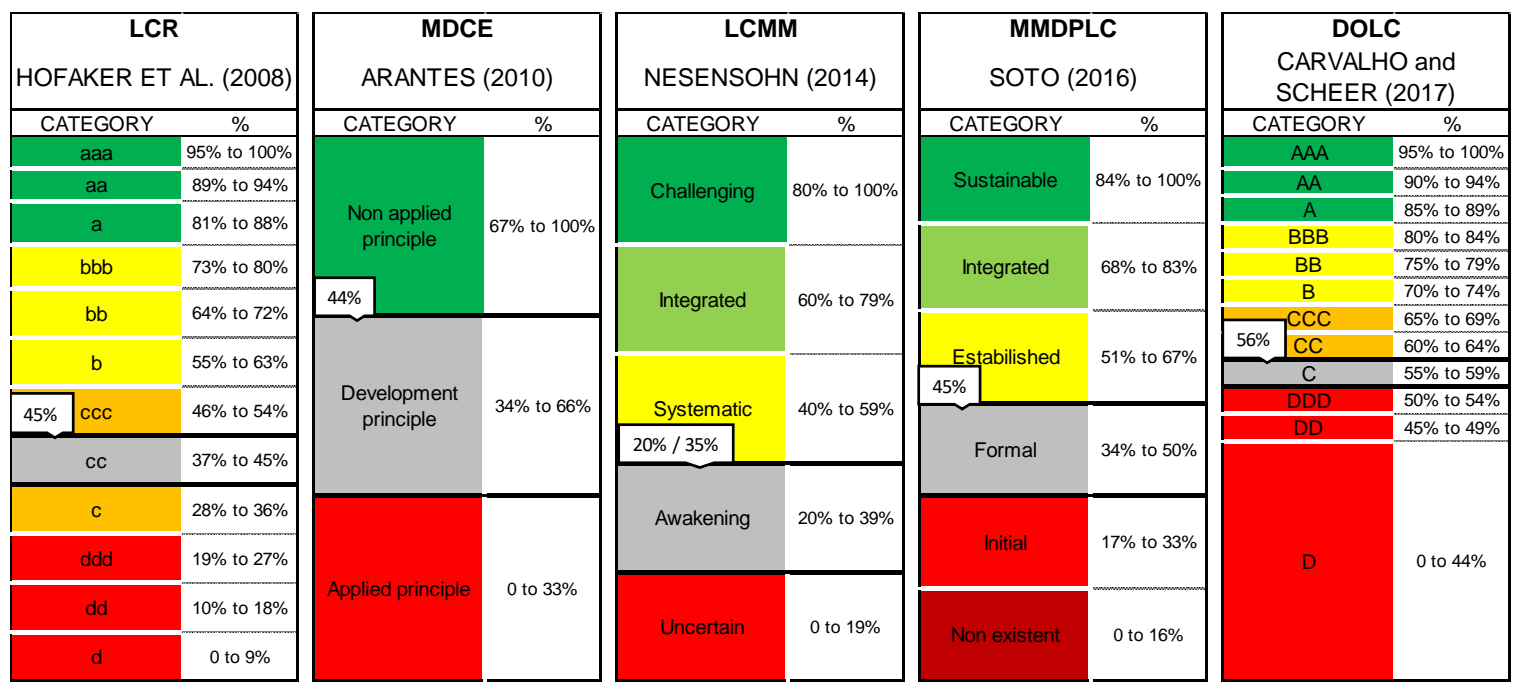

Figure 8: Comparison between the ranking scales of the models (own elaboration).

The applied MM have distant origins, this shows how different countries are concerned about assessing performance in LC philosophy and country progress in this journey. Lucena and De Mori (2018) analysed six Brazilian MM and concluded that DOLC method was an ideal application to evaluate Brazilian companies, not just each project. Carvalho and Scheer (2017) compiled papers that applied DOLC method in Brazilian projects and observed low adhesion and knowledge of the companies to LC. However, Salvatierra et al. (2015) evaluated LC awareness of Chilean companies and results confirm the Chilean pioneer in the LC application.

LCMM and MMDPLC propose self-assessment while others propose a third parties evaluation. The data collection method also differ, LCR, LCMM and MMDPLC use onsite visit and conversation with agents while DOLC and MDCE use structured interviews.

After evaluate the same project with five MM, the LC range of adherence was between 20 and $56 \%$, below the scale average of all authors proposed range, validating the five applications on this project since it does not apply LC formally. Considering six results, because of two different applications of LCMM, the average among all methods is $41 \%$ and all classifications had been below the central level of adhesion.

More levels scales have greater sensitivity to company development in the lean journey, with this the practices to be implemented get better orientation and the answers to the advancement efforts get more directed in LC trajectory. Mainly in the initial implementation phase of this philosophy where the change resistance as huge and is difficulty assimilating lean behavior.

Researches of GEPUC presented the Lean Triangle (Salvatierra et al. 2015) on each vertices represent fundamental points for the LC application, they are: culture, technology and philosophy. The methods used in this case study evaluate all triangle vertices, but by different approaches. LCR, DOLC and MDCE focus on tool application and philosophy itself, LCMM and MMDPLC assess accurately the culture organization evolution. 


\section{CONCLUSION}

Considering the data presented, are claimed about each method:

- LCR: focused on-site evaluation, restricted to a few questions and affirmations that allow a wide of answers due to the LC plurality, and the results can be distorted when different interviewers applied it or by the proposal data collection may be superficial;

- MDCE: focused only on the implementing LC agent, which can distort the results by the biased view of the interviewer, besides few classification levels can be limited the company's progress evolution in LC journey;

- LCMM: statements proposed to cover the diversity LC practices application, allows self-assessment requiring impartiality by the respondent, the classification scale is consistent with the advanced levels of LC, the attributes evaluation are rigorous;

- MMDPLC: evaluate the company's expectation about the principles and about the effective LC practices, as well as LCMM the evaluation of the practice as objective and broad at the same time, no visual results presentation but reveals project strengths and weakness and focus on what should be better applied, being a selfassessment tool request impartiality application;

- DOLC: covers internal and external project agents, demands strong adherence of the company and interviewed, may reflect the agents' expectations regarding their responses. The resulting scale with greater amplitude in the lowest level is coherent do to initial difficulty of the LC implementation, but as in the LCR responses may distort the real scenario.

After that, the authors consider LCMM the most appropriate method regards the application, results presentation and project final classification for this case study. For the Brazilian construction scenery, the maturity lake on LC application, Carvalho and Scheer (2017) reproduce the manager seizure when star the LC journey, questioning "how could I start". Nesensohn (2014) and consults experts answer that, this MM provide guidance to companies at any point in LC journey, making clear and exemplifying the plural practices of this philosophy, evaluating fundamental points of LC implementation.

LCMM method application is easily comprehended by researchers and construction site employees. Method application demand short time and adhesion of project professionals however broadly evaluate LC, embracing the plural presentation of this philosophy. The statements evaluated show examples of LC implementation and guide journey to the next level.

Nesensohn (2017) propose to each company use different attributes weight according to its values, allowing adaptation of the model to any market niche as well as increase the adhesion of employees to that. Nesensohn (2014) see the LC implementation journey as a permanent challenge without a higher level definition, because of construction processes are constant evolution and demand reinvented LC practices. This method is also best in organization culture evaluation, one of GEPUC Lean Triangle vertices, and it's the hard ascending levels used in this pepper. 
The authors point out that is interesting for companies who start lean journey and use LCMM guidance's, use the average of statements to the attribute value because, in this early stage, small evolutions can be misrepresented by the use of lowest statement value for the attribute, as proposed by Nesensohn (2014).

For future work, it is proposed a tool development for specific decision-making process to be applied prior the LCMM in order to verify the vision, mission and value most correlate attributes for the company and adjust its weights. In addition is necessary to apply this method in companies or projects with different lean maturity levels to validate the scale classification sensitivity.

\section{REFERENCES}

Alarcón, L. F., Grillo, A., Freire, J., and Diethelm, S. (2001). "Learning from collaborative benchmarking in the construction industry." Proceedings of 9th Annual Conference of the International Group of Lean Construction (IGLC), Singapore, Singapore.

Arantes, F. T. (2010). "Modelo de diagnóstico da maturidade da Construção Enxuta e estudo de casos em empresas da construção civil [Diagnostic model of the Maturity of Lean Construction and case study in construction companies]." Monograph to conclude civil engineering course - Universidade de São Paulo.

Ballard, G. (2000). "The Last Planner System of production control." Thesis (Ph.D.), School of Civil Engineering, The University of Birmingham, $192 \mathrm{pp}$.

Carvalho, B. S. de. (2008). "Proposta de uma ferramenta de análise e avaliação das construtoras em relação ao uso da construção enxuta [Proposal of a tool for analysis and evaluation of builders in relation to the use of lean construction]." Master's Thesis, Universidade Federal do Paraná, Brazil.

Carvalho, B. S. de, and Scheer, S. (2017). "Analysis and Assessment for Lean Construction Adoption: The DOLC Tool." Proceedings of 25th Annual Conference of the International Group of Lean Construction (IGLC), Heraklion, Greece, 429-435.

Hofacker, A., De Oliveira, B. F., Gehbauer, F., Freitas, M. D. C. D., Mendes Jr., R., Santos, A., and Kirsch, J. (2008). "Rapid Lean Construction-quality Rating model (LCR)." Proceedings of 16th Annual Conference of the International Group of Lean Construction (IGLC), Manchester, UK, 241-250.

Koskela, L. (1992). Application of the New Production Philosophy to Construction. Technical Report \#72, CIFE, Stanford University.

Lucena, A. F. E., and De Mori, L. M. (2018). "Critical analysis of Lean Construction measuring tools.” Brazilian Journal of Operations \& Production Management, 15(2), 311-321.

Moon, H.-G., Yu, J., and Kim, C. (2007). "Performance indicators based on TFV theory." Proceedings of 15th Annual Conference of the International Group of Lean Construction (IGLC), East Lansing, Michigan, USA, 141-146.

Nesensohn, C. (2014). "An innovative framework for assessing lean construction maturity.", PhD Dissertation, Liverpool John Moores University, UK.

Nesensohn, C. (2017). "A lean construction maturity model for organizations." Proceedings of 25th Annual Conference of the International Group of Lean Construction (IGLC), Heraklion, Greece, 357-365. 
Nesensohn, C., Bryde, D., Ochieng, E., Fearon, D., and Hackett, V. (2014). "Assessing lean construction maturity." Proceedings of 22th Annual Conference of the International Group of Lean Construction (IGLC), Oslo, Norway, 1157-1168.

Nesensohn, C., Bryde, D., and Pasquire, C. (2015). "A measurement model for lean construction maturity." Proceedings of 23rd Annual Conference of the International Group of Lean Construction (IGLC), Perth, Australia, 652-660.

Salvatierra, J. L., Alarcón, L. F., López, Á., and Velásquez, X. (2015). "Lean diagnosis for chilean construction industry: Towards more sustainable Lean practices and tools." Proceedings of 23rd Annual Conference of the International Group of Lean Construction (IGLC), Perth, Australia, 642-651.

Sarhan, S., and Fox, A. (2013). "Performance Measurement in the UK Construction Industry and its Role in Supporting the Application of Lean." Australasian Journal of Construction Economics and Building, 13(1), 23-35.

Soto, U. (2016). "Evaluación de la madurez de los principios Lean en proyectos de construccion [Evaluation of the maturity of Lean principles in construction projects]." Master's Thesis, Pontificia Universidad Católica De Chile, Chile.

Wettstein, T., and Kueng, P. (2002). "A Maturity Model for Performance Measurement Systems.” 10p. In: Brebbia, C.A. and Pascolo, P. (Eds), Management Information Systems 2002: GIS and Remote Sensing, WIT Press, Southampton. .

Womack, J. P., and Jones, D. (1997). "Lean Thinking - Banish Waste and Create Wealth in your Corporation." Journal of the Operational Research Society, 48(11), 1148.

Yu, I., Kim, K., Jung, Y., and Chin, S. (2007). "Comparable Performance Measurement System for Construction Companies." Journal of Management in Engineering, ASCE, 23(3), 131-139. 
Rodegheri, P.M. and Serra, S.M.B.

1092

Proceedings IGLC - 27, July 2019, Dublin, Ireland 